\title{
Semi-periphery and capital-intensive advanced technologies: the construction of Argentina as a nuclear proliferation country
}

\section{Diego Hurtado}

\begin{abstract}
Throughout the second half of the twentieth century a varied collection of pressure mechanisms were deployed from nuclear technology exporting countries - mainly from the US - to obstruct the development of a group of semi-peripheral countries' autonomous nuclear capabilities. Argentina was part of this group. This article focuses on how "fear" of nuclear proliferation was used by US foreign policy as one of the most effective political artifacts to construct and protect an oligopolistic nuclear market. Spread by the press and by some prestigious social science sectors from the US and some European countries, a persistent and dense discourse production was devoted over several decades to the bizarre practice of "calculating" the alleged hidden intentions of those semi-peripheral countries which aspired to dominate as many technologies of the nuclear fuel cycle as possible.
\end{abstract}

\section{Keywords}

Discourses on science and technology; Science communication in the Developing World; Nuclear Proliferation

Initially boosted by an industrialization political project which was connected to symbols of modernization and progress, the development of nuclear technology in Argentina has features which make it possible to evaluate it as the evolution - growth, diversification, and embeddedness - of a sectoral trajectory in the context of a semi-peripheral country. Through its evolution, the Argentine nuclear sector was able to shape what we could call a systemic environment, understood as an organizational arrangement which made it possible the development and exporting of some capital-intensive advanced technologies — primarily, but not solely, nuclear research reactors - which, after several decades, have shown to be competitive in the oligopolistic nuclear market.

New industries, according to Chase-Dunn and Reifer, "are important as the bases of hegemonic rises because they have huge spin-offs for the national economies in which they first emerge, [...] and because they generate 'technological rents' " [Chase-Dunn and Reifer, 2002], that is, great profits as a consequence of having the monopoly over the technologies which drive these new industries. From this perspective, some leading technologies can be seen as the primary causes 
of the emergence and sustenance of hegemonic economic cycles in the modern world system. As a new industry arising by the end of the Second World War, nuclear technologies have coevolved with - and have been a crucial component of - the distribution of power in the world system. In the geopolitical context of the Cold War, they were a condition of possibility for the consolidation of the first US hegemonic cycle. ${ }^{1}$

From the perspective of non-core countries, Argentina belongs to the category of "semi-periphery," defined by Wallerstein: "It is the normal condition of either kind of world-system to have a three-layered structure". Otherwise the system would disintegrate, because it would be "far less politically stable, for it would mean a polarized world system" [Wallerstein, 1974]. ${ }^{2}$ Evans associated the notion of semi-periphery to peripheral countries with an industrial capacity developed in the context - and integrated into - dependent development processes, characterized by the dominating presence of transnational capitals into the more dynamic areas of the domestic industry. As a consequence, Evans holds: "The distinctive position of semi-periphery in the international economy makes the course of dependent development in these countries critical to the future of imperialism" [Evans, 1979].

As a corollary, semi-peripheral countries turn out to be markets coveted by advanced countries either through turnkey sales, royalty payments, or technical assistance. However, systemic contradictions arise as a consequence of semi-peripheral countries' aspirations to develop and export advanced technologies to other peripheral countries as a way, not only of avoiding slipping towards the periphery, but also of encouraging economic growth and improving its influence and status in the regional sub-system.

For Hall and Chase Dunn, this attitude aims to transform the development "logic," that is, to challenge the rules of the game that core countries are trying to impose [Hall and Chase-Dunn, 2006]. For this reason, in the attempt of semi-peripheral countries to advance in the development of technologies that could facilitate the access to dynamic markets - precisely those that core countries try to keep for themselves-, semi-peripheral countries tend to be objects of obstruction or blocking strategies. As Ragin and Chirot explain: "The core needs a semiperiphery to balance the system, but it also fears the rivalry of advancing semiperipheral states [...] if they are too successful, may be frustrated by core action" [Ragin and Chirot, 1995]. To put the interests of core countries at risk is usually conceptualized by the hegemonic political "logic" as an alteration of "stability", that is, as a hazardous modification of the world system balance of power. The nuclear development of Argentina, Brazil, India, Pakistan, or South Africa, among other countries, seems to fit this characterization.

From this perspective, it could be interesting to analyze some examples of the varied collection of pressure mechanisms deployed in the international arena - mainly by the US - to obstruct the development of Argentina's autonomous capacities in the nuclear area. In particular, this article analyzes how "fear" of nuclear proliferation was used as one of the most effective political artifacts to protect the oligopolistic interests of the nuclear technology exporting countries. As

\footnotetext{
${ }^{1}$ An evolutionary approach on the role played by leading technologies in the emergence of new dynamic industrial sectors can be seen in: Modelski and Thompson [1996] and Rennstich [2008].

${ }^{2}$ Italics in the original.
} 
part of the US foreign policy, spread by the press and by some prestigious social science sectors from the US and some European countries, almost a genre in itself, this persistent and dense discourse production was devoted over several decades to the bizarre practice of "calculating" the alleged hidden intentions of those semi-peripheral countries which aspired to manufacture and export nuclear research reactors, to produce radio isotopes for local and regional markets, and to dominate as many technologies of the nuclear fuel cycle as possible.

Polysemy for exclusion

Juan Perón's administration (1945-1955) struggled tenaciously to integrate the technological factor into its program of government. As a political mark of Peronism and a trait to be assimilated to national identity, this government promoted in its initial stage the development of technological systems of various scales in sectors like aeronautic, energy, infrastructure, or civil engineering, among the most visible ones. In accordance with the international mainstream representation [Boyer, 1994], at the early 1950s, Peronism associated the promotion of atomic energy - as a powerful symbol of modernity and a promise of energy panacea - with the pursuit for technological autonomy and the deepening of the industrialization process [Hurtado and Feld, 2010].

As other countries, such as Brazil or India, Argentina attempted to take advantage of this initial stage of international opening and collaboration in the "peaceful uses of atomic energy". This context allowed a group of semi-peripheral countries advance the acquisition of its own human resources and material capabilities. During the 1950s and 1960s, Argentina was able to accumulate technological expertise for development of research reactors, as well as local production of radio isotopes to supply local demand. Regarding nuclear power reactors, natural uranium-heavy water technology was evaluated as the best option given the aim of minimizing the enriched uranium dependence from the US - the only supplier at the time - and, as a necessary complement, it was also promoted extraction and elaboration of uranium ore and the development of heavy water technology. Finally, considering the nuclear sector as a potential "industrializing industry", public investment should provide the means and incentives to the growth of a national nuclear industry. While it is possible to state, in hindsight, that there was no project to build an atomic bomb in Argentina, from the perspective of the US goals - supported by its geoeconomics partners - , as we will see below, this point did not seemed a relevant fact in the "classification" of Argentina as a proliferation country. ${ }^{3}$

The real problem seemed to be that the Argentine nuclear autonomy aspirations collided with the US projections about how it should be the structure of the global nuclear market. It does not seem a coincidence that, by the mid-1960s - when a group of semi-peripheral countries displayed the first signs that nuclear autonomy was possible, at least in some not too complex areas - , the matter of "nuclear proliferation" began to be amplified in the international arena. On the semantic surface of this concept was the nuclear powers concern for the development of technologies which facilitated the access of Third-World countries to the building of atomic explosives. However, in a more subtle second layer of meaning, the concept of proliferation combined with the matter of "the advance of communism" - the

\footnotetext{
${ }^{3}$ See: Hymans [2001] and Hurtado [2014].
} 
political vehicle for the promotion of military dictatorships in Latin America opened a horizon of limitless possibilities for the deployment of pressure devices on the Argentine nuclear program. While dictatorships were synonymous of political instability, the supposedly best guarantee required as a proof of peaceful intentions in the uses of atomic energy was democracy and political stability.

Loaded with ambiguities and asymmetries, the selective polysemy putting into circulation with the nuclear regulatory framework globally promoted through the Non-Proliferation of Nuclear Weapons Treaty (1968) started a process of naturalization of what shall be conceptualized more than two decades later as a "nuclear apartheid", according to the expression used in the early 1990s by the former chancellor of Raúl Alfonsín administration [Clarín 1992], when even after the return to democracy Argentina had to continue to undergo the pressures of the US.

\section{"Peace institutes" and international "experts"}

Plutonium technology shows how this exclusion machinery works. In 1968 a pilot plant for plutonium reprocessing was put in operation in the National Atomic Energy Commission (CNEA) in Buenos Aires city. The following year less than half a gram of plutonium could be separated from a burnt fuel element of a research reactor. At this moment, the Argentine nuclear program interests in plutonium were connected to the possibility of a future access to a technology being highly promoted by the nuclear powers. Plutonium technology promised huge advances in the performance of nuclear fuels.

In June 1972, the local press published an evaluation of the Argentine nuclear development made by SIPRI Yearbook, the prestigious publication of the Stockholm International Peace Research Institute (SIPRI). ${ }^{4}$ The analysis covered fifteen countries which had not signed or ratified the Non-Proliferation of Nuclear Weapons Treaty (NPT). SIPRI Yearbook stated that Argentina was the most advanced Latin American country in the nuclear field and recognized: "Like Brazil, Argentina is primarily concerned with the contribution of nuclear energy to economic development". Also, it explained that "Argentina has not been so demanding as Brazil regarding the right to develop and use peaceful nuclear explosives". Considering the plutonium reprocessing plant at CNEA's Centro Atómico Ezeiza (province of Buenos Aires), SIPRI's publication noted that "Argentina is one of the few countries of the world other than the nuclear-weapon powers which has a chemical separation plant, although its output is small". Now if it was considered that "Argentina also has substantial uranium deposits", the entire set of capabilities placed this country "one stage closer to a future nuclear weapons option" [SIPRI, 1972, pp. 332-333].

In a comparative table which includes the fifteen countries analyzed, SIPRI Yearbook pointed out that Argentina had a "Small chemical separation plant" and a power reactor under construction; at the item "Approximate annual product. of plutonium $(\mathrm{kg})$ ", it was indicated "200" and at the item "Estimated annual product. of plutonium $(\mathrm{kg})$ " it was suggested "400" for 1977, since it was supposed that Argentina would have two nuclear power plants operating in that year [SIPRI, 1972, pp. 296-297]. That is, while Argentina had produced until that moment less

\footnotetext{
${ }^{4}$ See, for instance, La Prensa [1972].
} 
than half a gram of plutonium, SIPRI's comparative table suggested that it already had the capacity - or it was already producing - 200 kilograms per year, contrary to the column in which they pointed that the only nuclear power plant which could produce that plutonium was still under construction.

It seems an interesting issue, at least from the perspective of semi-peripheral countries, to explain why "experts" in nuclear proliferation quickly reproduced this wrong quantity - 200 kilograms of plutonium - without any mention of the context. The nuclear "expert" John Redick, since 1970 Research Associate at the Stanley Foundation in Muscatine (Iowa), explained in the first pages of your book titled Military Potential of Latin American Nuclear Energy Programs: "It is a basic assumption of this paper that there has been no decision by any Latin American nation to develop nuclear weapons". However, he added, "the present paper deals with what are believed to be the current realities endemic to the Latin American nuclear programs: i.e., peacefully oriented but with military potential" [Redick, 1972, p. 5]. If this argument seems curiously ambiguous - i.e.: anyone can use a broomstick to manufacture a spear —, the author attempts to shed some light on it:

\footnotetext{
"The existence of civil nuclear program does not necessarily imply the future development of nuclear weapons. However, the political climate within a nation can change rapidly: intentions can be altered with a shift in governments, in response to a perceived external threat and many other factors. The important point is that the unavoidable by-product of the development of nuclear power productions is a military potential" [Redick, 1972, p. 5].
}

And a little further down, Redick finally displays the motivation of this basic but entangled syllogism: "Five to 10 kilograms of plutonium are sufficient for construction of a nuclear bomb which can obliterate a medium-sized city". And afterwards he repeated SIPRI's data which estimated that Argentina and Brazil would produce "400 and 190 kilograms respectively by 1977" [Redick, 1972, p. 10].

The way that Redick's book focuses on natural uranium reactors is a didactic example of how the "experts" rhetoric works on nuclear matters. In a confusing paragraph which, among other distortions, omits opening quotation marks, Redick explains:
"With respect to the possible development of nuclear weapons by Argentina, it is of note that one of the purposes of the CNEA was defined, at the time of its creation, as 'to propose to the chief executive the necessary provision to be adopted for the defense of the nation.' Nearly twenty years later, an official of the CNEA openly acknowledged a possible military role by describing the commission as a powerful government organ of considerable autonomy answerable to the chief of state' "with direct responsibility ... [for] the production and utilization of nuclear energy for peaceful and warlike purposes' (Sabato 1968, pp. 333)" [Redick, 1972, pp. 15-16].

A brief exegesis of this quote displays the "hidden intentions" of the author. The first phrase quoted by Redick is taken from the decree 10,936 of May 1950 by which CNEA was created. The quoted "CNEA official" is, as can be seen in the final 
parenthesis, Jorge Sabato, an Argentine technologist specialized in metallurgy, member of CNEA between 1954 and 1970, and, at the moment Redick was writing, also a regional referent in technological policy issues. Sabato's words were quoted from an article he had published few years before in a Chilean magazine. Sabato's phrase quoted by Redick (who suggestively forgot to open the quotation marks), which seems to apply to CNEA - we will see that the original did not -, is taken from a paragraph in which Sabato speaks of the importance of the emergence of nuclear energy on the planet. But, when translated into English, is cut out and altered - a plural form is turned into a singular one - to change its sense. Sabato says in the original:

\begin{abstract}
"Fue así que nacieron las Comisiones de Energía Atómica, órganos de gobierno dotados de gran autonomía y poder (dependientes generalmente en forma directa del jefe de Estado), con responsabilidad directa en la ejecución de todo aquello conducente a la producción y utilización de la energía nuclear, sea para fines pacíficos o para fines bélicos. Su creación en los países más avanzados (la de EE.UU. lo fue en 1945) naturalmente impulsó a los demás a seguirlos. Y así fue que la Comisión Nacional de Energía Atómica de la Argentina se creó el 31 de mayo de 1950 [... ]" [Sabato, 1968]. ${ }^{5}$
\end{abstract}

To understand the motivation that could lead to the "mistake" and the consequently alteration of the quote, we need to advance a bit further in the "expert" argument:

\begin{abstract}
"Argentina's posture on nuclear arms control efforts plus its ambitious nuclear power program has led to concern by some that there has been a national decision to develop nuclear weapons as was expressed in a paper presented at the Twelfth Annual Pugwash Conference in Sochi, USSR, in October 1969. It was suggested that Argentina is mobilizing its physicists to make possible this achievement within ten to fifteen years. It was also argued that the Argentine government was motivated by fear that a Castro-type revolution in Brazil might threaten the security of the nation (New York Times, 1969)" [Redick, 1972, p. 16].
\end{abstract}

Let's focus our attention on the New York Times article which is the source alluded by Redick. The article started like this: "Scientists attending the 12th annual Pugwash Conference have heard that Argentina appears to be developing the ability to produce nuclear weapons". Who said this? A subtitle of the article reveals the source: "Speaker Is Unidentified". Further on, it explained that Argentine developments were presented by a "specialist" connected to the international effort of "avoiding the proliferation of nuclear weapons". The author of the article, Walter Sullivan - renowned science editor of the New York Times -, explained that the specialist's anonymity was part of "the conference rules", which "are intended to encourage candor and to allow participants to make unorthodox proposals without committing themselves or their governments". What was the unorthodox argumentation about Argentina? Sullivan told that the unidentified speaker explained that: "By 1972, according to the report, Argentina will have a 316-megawatt reactor capable of producing plutonium usable in nuclear weapons" [Sullivan, 1969]. We return once again to the argument deployed by

\footnotetext{
${ }^{5}$ Italics added.
} 
SIPRI, which means that Redick's only true piece of information was Argentina's decision to have a natural uranium reactor. The nuclear "expert" concluded: "It is difficult to escape the conclusion that the path chosen by Argentina in developing its civil nuclear capacity lends itself more easily to weapons development than others which it might have followed" [Redick, 1972, p. 17].

In May 1974, India's unexpected nuclear test led nuclear technology exporting countries to begin to meet in secret. The meetings of this group, which was going to be known later as the "London Club" (later Nuclear Suppliers Group), were initially led by the US Secretary of State Henry Kissinger. Its explicit aim was to put restrictions on the trade of nuclear equipment and technologies, and additionally to negotiate in order to prevent that the exporting ambitions of the London Club members themselves jeopardized those restrictions. Ignoring IAEA, the London Club aimed to define, for an indefinite period, a new and more restrictive boundary between, on one side, the few countries that possessed capabilities to develop the complete nuclear fuel cycle and, on the other side, the rest of the countries, which had to resign themselves to the role of importers. ${ }^{6}$

In parallel with this initiative, a group of "experts" helped reinforce a climate of suspicion. Redick himself stated in 1975 that: "The similarities between the Indian and Argentine nuclear energy programs are apparent". For this author, the conclusion was obvious: "[...] it is difficult to escape the conclusion that each step of the Argentine nuclear energy program appears to have been designed to lend itself most readily to weapons development" [Redick, 1975].

This kind of statement was emphatically denied by the civilian spokespeople of CNEA. "We have no military program and what's more we can't have right now", attempted to explain to Washington Post the Argentine chemical engineer Jorge Cosentino, who was in charge of the operation of Atucha I nuclear plant since its inauguration in March 1974. ${ }^{7}$ And he added: "We produce 100 kilograms of plutonium per year at Atucha, but its not the right composition as it comes out of the reactor. To make it the right composition, I'd have to change fuel elements every hour, not every day". In the same article, Mario Báncora, head of CNEA's División de Reactores - reactors division — held: "The only thing the Indian bomb did for us was to complicate our lives terribly" [Novitski, 1974].

Meanwhile, Jorge Sabato held that "the choice of a natural uranium-heavy water line necessarily means reprocessing burnt fuel to obtain the indispensable plutonium to develop plutonium-uranium mixed oxide fuel which [Argentina] could use in its future reactors". These choice, he added, "coherent and rational, stumble into the firm opposition of central countries which, with the pretext of preventing nuclear weapons' proliferation, try to prevent by all means developing countries from reaching full command of reprocessing and enrichment techniques" [Sabato and Frydman, 1976].

The superficiality and lack of consistency (at this point we could speak of hypocrisy) of the regulations and arguments against nuclear weapons proliferation that circulated in the international arena was proved by the agreements achieved

\footnotetext{
${ }^{6}$ See, for instance, Hofmann [1976].

${ }^{7}$ A heavy water-natural uranium reactor, Atucha I had been built by the German firm Siemens with an estimated participation of Argentine firms of around $40 \%$.
} 
by CNEA's chairman during Argentina's last dictatorship, which was already questioned at that time for severe violation of human rights. However, the de facto Argentine government (1976-1983) managed to achieve nuclear assistance agreements with West Germany, Canada, Italy, Switzerland, the US, Great Britain, the Soviet Union, China, and France. ${ }^{8}$ That is, for the London Club members the interest to trade nuclear technology seemed to be far above the secret agreement - or any other consideration - to avoid the alleged incentives to proliferation that this trade might promote.

\section{Poverty as a guarantee of non-proliferation}

During the return to democracy, in the mid-1980s, in an environment of extreme financial limitations which had their roots in a huge debt inherited from the authoritarian government, as we will see in this section, US diplomats tenaciously attempted to hinder the Argentina's nuclear development through a tactic focus on two connected topics: on one side, the supposedly political instability, caused by economic fragility, as a threat to the return of the military to the government; on the other side, the threat of blocking loans of international credit organizations, which would deepen economic crisis [Hurtado, 2014, pp. 252-258].

In 1984, in the pages of Wall Street Journal, one could read: "The U.S. cannot entirely discount the possibility that Argentina might at some point be governed by military lunatics eager to express their patriotic fervor by building 'the bomb' ". And the same article added that "Mr. Alfonsín essentially has adopted his military predecessors' policy line on this issue" [Leigh, 1984].

That same year, Walter Patterson, a contributing analyst to the British publications New Scientist and The Guardian, published a lengthy essay in an editorial of the prestigious Bulletin of the Atomic Scientists titled "The Plutonium Business and the Spread of the Bomb" for the British Nuclear Control Institute. There he said:

"[Argentina] built a pilot reprocessing plant at its nuclear research centre at Ezeiza near Buenos Aires. The plant operated from 1969 to 1972. Strange discrepancies emerged - and lingered — about its capacity. [... ] However, the independent and authoritative Stockholm International Peace Research Institute put the figure at 200 kilograms per year" [Patterson, 1984].

In a context of increasing budgetary weakness in the Argentine nuclear program, according to an article published by the Houston Chronicle, "U.S. officials continue efforts to get Argentina to sign the two nuclear treaties to control the impact of its export activities". The article also referred to the "horrendous economic conditions", which "has heightened concern that Argentina's possible return to military government could rekindle an interest in the bomb among the iconoclastic, nationalistic, unpredictable and sometimes bellicose Argentines". This winding argumentation ends up saying: "U.S. technology is also held out as a carrot" [Oster, 1985]. That is, now that Argentina was a democracy, the problem seems to be, on one side, its capacity to export and, on the other side, the economic instability that

\footnotetext{
${ }^{8}$ It should be included, since the middle of 1982, the supposed proliferating consequences of the Malvinas War. About this topic, some titles in US newspapers may be seen in: Kondracke [1982], International [1982] and Christian Science Monitor [1982].
} 
opened the possibility to a new military dictatorship. The solution — or at least a partial solution - would be the sale of nuclear US technology.

During that period, Argentina-Brazil integration initiatives began a successful nuclear collaboration process which partially deactivated arguments which forecasted a supposedly potential nuclear escalation as a consequence of the rivalry between these neighbor countries. Thus, after the meeting which took place in the Brazilian border town of Foz do Iguaçu by the end of November 1985, where the democratic Argentine and Brazilian presidents, Raúl Alfonsín and José Sarney, signed the "Declaración conjunta sobre política nuclear" — joint statement on nuclear policy -, unmoved by these integration initiatives, the prestigious SIPRI's yearbook of 1986 offered an interpretation of the unprecedented collaboration process between Argentina and Brazil, which was one of the main steps that paved the way to the creation of the South Common Market or Mercosur. ${ }^{9}$

Referring to Argentina, SIPRI held that "its policy of acquiring all the elements of a nuclear weapon program has born no fruit: it has not improved the security of the state, its international standing, the cohesion of the nation or the material conditions of the people". It further added that "the precise targets of possible nuclear weapons have always been obscure". That is, Argentina might have been pursuing a nuclear weapons program without definite objectives. Regarding Brazil, after referring to "the grandiose nuclear energy projects, entirely unwarranted by the country's natural resources", it concluded: "In any event, Argentina and Brazil are at present in economic straits that ought to rule out nuclear weapons programs" [SIPRI, 1986]. Thus, contrary to what both Latin American neighbor countries publicly expressed as motivation for their collaboration, the Argentine-Brazilian approach is presented as a consequence of the failure of their supposedly ambitious and ambiguous nuclear programs, and the economic crises of both countries were interpreted as a guarantee to avoid them.

In 1987, Cynthia Watson - an "expert" in proliferation who had completed her Ph.D. a few years before at the University of Notre Dame with a thesis titled "Argentine Nuclear Development: Capabilities and Implications" — referring to Brazil and Argentina, stated: "But the light at the end of the tunnel for those concerned with the spread of nuclear weapons and nuclear industry is that the very economic crises facing these states is likely to prohibit any grandiose nuclear expansion for the next few years" [Watson, 1987]. That is, as for SIPRI, for this expert the poverty of semi-peripheral countries was finally a source of hope for nuclear technology exporting countries. Note that Watson was concerned not only about nuclear weapons but also about nuclear industry.

By the end of the 1980s, for the prestigious Bulletin of the Atomic Scientists, the possibility that presidential elections were won by that "Argentina's ultranationalists" shed a veil of uncertainty over the continuity of the Argentine-Brazilian relationships. In an article published in 1989 titled "Peronists seek 'nuclear greatness'" the author stated: "If opinion polls are to be believed, Argentina's authoritarian and xenophobic Peronist mass movement will return to power in general elections on May 14." And a little further, he added: "That prospect has prompted renewed concern over nuclear development in Argentina, a country with a long history of political instability and militant nationalism." In the

\footnotetext{
${ }^{9}$ For an exhaustive treatment of the precedents of the Foz do Iguaçu meeting see Mallea [2012].
} 
same publication, CNEA is qualified as a "secretive, sclerotic, and inbred" agency [Kessler, 1989].

However, a few months later, after the Peronist candidate Carlos Menem took office, in the same publication, one could read the title "U.S. endorses Menem's nuclear plans" and a lead which explained: "U.S. ambassador lauds Argentina's impeccable nuclear record". The article told that the US ambassador Richard Kennedy, after visiting Buenos Aires in May 1990, had argued before journalists that "there is little if any cause for suspicion" that the Argentine nuclear program had military purposes. Showing some perplexity, the author of the article complained: "Kennedy could not say why the United States, after decades of doubt, now believes Argentina's nonproliferation pledges, given the continued secrecy surrounding its fuel cycle plants." Still without detecting the first signs of the unconditional alignment with the US policy which Menem's government was beginning to promote, the author of the article held: "Meanwhile, political analysts say the United States will miss a golden opportunity, as Argentina comes hat in hand, asking Washington for funds to bail out its shattered economy" [Goldman, 1990].

In 1995, when Menem's government promoted — as part of the downsizing of State policies and privatization of public companies - the dismembering of the Argentine nuclear program, Mitchell Reiss, researcher of the Woodrow Wilson International Center for Scholar, in Washington D.C., published a book titled Bridled Ambition. Why Countries Constrain Their Nuclear Capabilities. There, Reiss reasoned:

\begin{abstract}
"During the 1970s and much of the 1980s, Argentina was one of a handful of countries suspected of wanting to acquire nuclear weapons. Foreign observers cited numerous motives for an Argentine bomb program: to win status and prestige; to vault over other South American countries, especially Brazil (and thus fulfill the traditional Argentine desire for 'exceptionalism'); to secure popular approval for illegitimate military regimes; to maintain a technological and scientific lead over its neighbors; and perhaps most important, to hedge against the possibility of Brazilian nuclear bomb" [Reiss, 1995].
\end{abstract}

It is remarkable that in this quote the only reason that was repeated again and again by CNEA's technologists and officers as well as by Argentine diplomats for more than 40 years - that Argentine nuclear program sought to produce electricity, to promote the growth of a national nuclear industry and to gain technological autonomy to compete in the international nuclear market, an objective which Argentina had managed to display it was possible at the time of Reiss's book publication with, for instance, the exportation of research reactors to Peru, Egypt, and Algeria - was not even remotely considered. ${ }^{10}$

An evaluation from the nineties
In 1996, Etel Solingen — prestigious professor at the University of California (Irvine) - published a book devoted to analyze the evolution of Argentine and Brazilian nuclear sectors. In the final conclusions, with reference to Argentina's emphasis put on "the nuclear industry's potential to induce backward linkages through domestic procurement of equipment and services", the author holds:

\footnotetext{
${ }^{10}$ About Argentine nuclear technology exports until the end of the nineties, see Buch [1998].
} 
"The outcome of CNEA's dedicated efforts in this direction suggests that the nuclear sector may hold little promise as a 'heartland' technology, particularly when compared to automobiles and microelectronics. Not only were multiplier effects quite limited in both Brazil and Argentina, but they also absorbed resources from sectors with greater developmental potential" [Solingen, 1996, p. 188].

Regardless that the comparison with the automobile sector takes reference data from 1974 - based on the quantity of local companies supplying spare parts and employed people - and that this industrial sector began to be decidedly promoted in Argentina at de 1950s, Solingen's argument loses sight of the structural differences between automobile and nuclear sectors [Solingen, 1996, pp. 166, 259, footnote 122]. About automotive industry, Argentine economist Jorge Katz says that at a global scale, in the 1990s, the transition towards new organizational models "took Ford Argentina to become an assembler" which "has left behind a production organization model based on a high level of vertical integration and local manufacturing of spare parts"; that external provisioning "does not justify to deepen the technological bond with local producers"; and that "product design and process engineering departments of the firm ceased to make sense" [Katz, 2009]. As regards microelectronics, the other example mentioned by Solingen, let $̂ t^{\prime}$ 's say that the trajectory of this industrial sector was especially dramatic in Argentina. So, it is hard to believe that the author had any information of the development of electronics in Argentina. ${ }^{11}$ The other "sectors with greater developmental potential" are not specified. Was this evaluation put forward by Solingen - politically correct for its academic context and tailor-made for the debacle the Argentine nuclear sector was undergoing as a consequence of neoliberal policies promoted by the unrestrictive alignment with the US in force at the time of the publication of her book - a product of an analysis methodology? Or was it induced precisely for the knowledge of the point of arrival and a preconceived position, suitable to celebrate the dominant neoliberal ideology?

The first thing to be noted is that Solingen's book presents serious contextualization problems. With reference to physics, for instance, it holds: "The beginnings of Argentine physics are paradoxically associated with fraudulent attempt in 1951 by an obscure Austrian physicist with delusions of grandeur - Hans [sic] Richter to convince President-General Perón that he could produce a hydrogen bomb" [Solingen, 1996, pp. 114-115]. ${ }^{12}$ Let's remember that, in contrast with these statements, there was already in 1910 at the Universidad Nacional de La Plata - National University of La Plata - a physics institute which brought together a core of German physicists - Richard Gans and Johann Laub among them - who took in charge the training of the first generation of Argentine physicists, ${ }^{13}$ and that the Asociación Física Argentina - Argentine Physics Association - was created in 1944, when there already existed a small local physics community. On the other hand, it was not the hydrogen bomb what motivated Peron's government to create CNEA in 1950. On the contrary, the motivations were more elaborated and

\footnotetext{
${ }^{11}$ About the evolution of the "electronic complex" in Argentina and the tortuous trajectory of advances and retreats, losses and recoveries of capabilities at the beginning of the 1990s, see: Nochteff [1992].

${ }^{12}$ The name of the Austian physicist is Ronald Richter. Throughout the book on two occasions Juan Domingo Perón is referred to as "Juan M. Perón".

${ }^{13}$ Created in 1906 as Escuela Superior de Física, in 1909 it was named Instituto de Física. See: Pyenson [1985].
} 
comprehensible for a country that was decidedly promoting a process of import substitution industrialization and the diversification of its energy sources with the goal to lessen its dependence on imported coal from Britain. All of that in a moment that was taking place an intense promotion of nuclear energy in the international arena.

Another visible example of the weakness of Solingen's analysis refers to the public company INVAP - a CNEA's spin-off. The only achievements of this firm mentioned by the book are the manufacturing of zirconium sponge and the research reactor RA-6. Solingen does not consider that INVAP participation in the project of uranium enrichment at the end of the 1970s or in the export of a research reactor to Algeria - both initiatives erroneously attributed to CNEA - , or this company's diversification towards the space sector were relevant data to assess the economic performance of Argentine nuclear sector [Solingen, 1996, pp. 29, 164].

Initiatives promoted by the "international security regime" - mainly Tlatelolco Treaty, TNP and the secret agreements by the "London Club" - , according to Solingen, "had only a marginal impact on the industrial an technical characteristics of nuclear programs of newcomers in general and of Brazil and Argentina in particular" [Solingen, 1996, p. 88]. On one side, the use of the term "newcomers" is suggestive - what does this word mean? - if we consider that both Argentina and Brazil began the process of institutionalization of the nuclear area by the end of the 1940s. On the other side, it seems that Solingen does not take into account the dense and persistent fabric of diplomatic pressures, as well as the suspicions and accusations of proliferation which were spread through academic activities and the US press over more than two decades. If we would assume Solingen's position, we should accept the economic insignificance of international relations, judging by the intense formal or informal diplomatic activity deployed by US around Argentine nuclear development. But even more problematic, if we generalize this perspective, the irrelevance of US pressures would suggest the possibility that Argentina's condition as a developing country is the consequence of a purely endogenous dynamic. Thus, as this position rules out the possibility that the Argentine-Brazilian bilateral nuclear collaboration was conceived as a mean to deactivate or weaken international pressures, Solingen ends up adopting Redick's position when she interprets this bilateral collaboration "as an effort to build a joint nuclear export capability" which, until the mid-1980, "was premised in the attractiveness of Brazil and Argentina as nuclear suppliers outside the Western regime of restrictions and control" [Solingen, 1996, p. 165]. What does "attractiveness" means in this context?

If Argentina and Brazil do not collaborate, then there exists the danger of nuclear escalation. If these countries collaborate, then it is clear that their aim is to put themselves outlaw. In either case, it seems unthinkable to the hegemonic nuclear think tanks that this nuclear approach may be interpreted as an institutional innovation conceived as a guarantee of nuclear non-proliferation which at the same time sought to keep nuclear autonomy and to strengthen capabilities by mean of bilateral collaboration. In fact, as a result of a long historical process this nuclear collaboration led to the creation, at the early 1990s, of the Brazilian-Argentine Agency for Accounting and Control of Nuclear Materials (ABACC), responsible for mutual verifying of the pacific use of nuclear materials. 
Finally, regarding the disastrous and corrupt privatization cycle of public companies during Carlos Menem's first presidency (1989-1995) at the beginning of the 1990s, carried out under strict supervision of the international credit organizations and considered by Solingen as "one of the most active privatization spurts in Latin America", she explains: "This general push toward privatization dismantled much of CNEA's traditional domain, even though — somewhat paradoxically - this was a logical outgrowth of the old policy of state subsidiarity" [Solingen, 1996, p. 72]. This is a strange conceptualization - which is worked on throughout the book - which is essentially opposite, for instance, to the conceptual scheme known as "Sabato triangle", which inspired at least two decades of Argentine nuclear policy. According to Sabato triangle, the strategic part played by the State as an active promoting agent of capabilities accumulation in strategic areas - nuclear, oil, machine tools, infrastructure, etc. - does not allow in any way for the assimilation of the role of the State to the neoliberal context of privatizations and stigmatization of the State intervention which were characteristic of the 1990s. ${ }^{14}$ Solingen concludes in the end of her book:

\begin{abstract}
"It is possible to strengthen scientific, technological, and entrepreneurial capabilities directly at much lower costs than via programs of this nature [...]. In sum, at the very least, the evidence from this study of direct budgetary and opportunity costs suggests the need for developing countries to reevaluate their view of nuclear technology as a developmental panacea" [Solingen, 1996, pp. 188-189]. ${ }^{15}$
\end{abstract}

Again, but this time from a methodological perspective, considering the limitations inherent in any sectoral analysis - which additionally does not consider any other variable related to the rest of the research and development Argentine complex -, it is suggestive to note that Solingen draws conclusions that go beyond the nuclear sector, involving "scientific, technologic, and entrepreneurial capabilities" to a national scale, putting aside the fact that at that moment these capabilities were also being devastated by neoliberal policies. In addition, we must not overlook that the quoted conclusion, according to the author, would not apply only to Argentina or Brazil, but to "developing countries", as if the national historical specificities were not relevant for this set of countries. In the cases of Argentina and Brazil, the final advice the author gives does not consider the forty-five years of investment in the nuclear sector. It seems a bit naive to think that after the huge obstacles and difficulties that the Argentina and Brazil nuclear programs had to face, these countries could conceive at the 1990s that the nuclear sector was a "developmental panacea." At any rate, a lesson painstakingly learnt by those involved in the promotion of technological programs in peripheral and semi-peripheral contexts was that there are no technological panaceas.

Ultimately, according to Solingen's book, physics did not begin in Argentina before the 1950s; its first steps stem from a "fraudulent attempt"; Perón wanted the hydrogen bomb; international regulations which tried to downgrade semi-peripheral nuclear developments and stubborn external pressures along more than three decades had not any influence; Brazil and Argentina begun a

\footnotetext{
${ }^{14}$ About the Sabato triangle, see: Sabato and Botana [2011]. About its diffusion outside Argentina, see: Etzkowitz and Leydesdorff [2000].

${ }^{15}$ Italics in the original.
} 
collaboration process because of the attraction of being outside the international control regime; etc. As a parallel reality, the history seems very different if we consider the few examples of pressures which have been succinctly presented here and interpret them in the context of the sequence of coups d'état promoted in Argentina - and in other Latin America countries - since the 1960s, along with the transnationalization of the Argentine economy, as well as the deindustrializing consequences of the neoliberal political economy deployed by the last dictatorship and deepened by the huge foreign debt that democracy inherited from this authoritarian period, and the fierce neoliberalism politics of the 1990s which finally led to the political and economic collapse of the country in 2001. These events seem either not being taken into account or being interpreted as neutral by Solingen's evaluation.

The goal of this brief and somewhat shallow review of what may be considered some of the weaknesses of Solingen's book - published by Stanford University Press - attempts to highlight the continuity, throughout the 1990s, of a dominant perspective within Anglo-Saxon academy which assumes the periphery as a place where social, political, and economic processes are opaque, but also simple. It is opaque because historical processes use to be driven, or at least influenced, by supposedly hidden intentions. But, at the same time, the implicit consideration of simplicity justifies the lack of rigorous analysis. From these premises, the final products are arguments which have an ethnocentric common sense as ultimate ground. This kind of perspective would be unthinkable in equivalent studies which had a core country as object of analysis.

By selecting some meaningful examples, this article has tried to display how from the academic and journalistic sectors of the US, in synchrony with academic institutions of some European countries, a discourse based in proliferation suspicions was built which aimed to hinder Argentine autonomous nuclear developments, and how the notion of proliferation was functional to the protection of oligopolistic positions in the nuclear market that core countries preserve for themselves.

The notion of nuclear proliferation was born impregnated with multiple political ambiguities which stem from the selective meanings assigned by core countries to every technology which they considered to be strategic. The discursive machinery that initiated and accompanied the complex and contradictory reordering of the international field of forces triggered by the construction of the international nuclear market ends up taking the shape of a bizarre "science" of calculating intentions. Deployed by an army of "experts" in foreign affairs, its function was to reproduce the rituals and the scenarios of the social sciences to display which, on the surface of this practice, seemed to be its object of analysis: the structure of hidden - and generally inconfessable - motivations which drives a semi-peripheral country towards the development of a sensitive technology.

Underneath this visible surface, the methodology guiding this practice was conceived during the Cold War to work as another instrument of the implicit hegemonic objectives and, in the same direction, in favor of oligopolistic interests of nuclear technology exporting countries. In short, this multi-faceted political coercive device, which borrowed the scenery of the academic world and some 
formal aspects of the social sciences, knew beforehand the results of its analysis: any semi-peripheral country with autonomous nuclear technological capabilities was a proliferation country. Presented as an academic practice, this political machinery takes on as a postulate the opaque and unstable nature of the periphery. All in all, what is interesting to point out is the evidence of an operation of construction of peripheral opacity as a legitimate practice of the social sciences, as an activity of "knowledge" production which is later used to promote restrictions, sanctions, and formal and informal pressures as justified and naturalized resources in the international arena.

On the other hand, the periphery is opaque (it hides its true intentions), but simple, or at least far more simple than core countries. Why is it important to construct simplicity while at the same time opacity is being constructed? Because what is simple is predictable. Thus, simplicity works as an epistemic value. If the periphery is simple, it is feasible to infer its intentions, even if they are hidden. This statement is backed up by the absence of in-depth studies about Argentine nuclear development which endorse the arguments of "experts" presented in this article. Thus, the condition of possibility for granting scientific status to the inference of hidden intentions is the periphery and semi-periphery's simplicity.

But if their intentions have to be inferred, it is because they are not those declared by their scientists, engineers, diplomats, or government representatives. From a more subtle methodological perspective (probably unmentionable), to understand with the goal of explaining is a practice different from to normalize with the goal of controlling. The epistemological nature of the problem and the ontological status of the object (in this case a semi-peripheral country) justify the functionality level of a kind of knowledge which, even though normative, pretends to be descriptive. The category of "proliferation country" fulfills these requirements: it does not describe, it prescribes that certain types of countries does not have to exceed a certain threshold in the autonomous development of certain technologies. Which kinds of countries, which thresholds, and which technologies, are determined by geopolitical and geoeconomic "stability".

This strategy of argumentation is a powerful political resource which core countries have been deploying - and improving - since the Second War World to downgrade the efficacy of technological policies of semi-peripheral countries. It is a particular manifestation of a feature which is in the essence of capitalism. That which is dangerous for its power to produce controlled transformations - destructive or constructive - is precisely what the market logic defines as costly and coveted. The capacity to produce controlled transformation defines technology. If this capacity is enough to alter global stability - military or economic - the technology is classify as sensible. To produce energy, to industrialize, to incorporate added value to local processes of production, it means also to become dangerous: in the market and at war, which are both the battlefields where the place of each country within the world system is decided.

Knowing retrospectively that Argentina never had a nuclear weapons program, the "constructivist" arrogance of the discursive devices set up to protect the oligopolistic structure of the technology markets does not have either the interest or the serenity to evaluate and correct the dramatic manipulation of the proliferation concept which distorts and weakens its future applications. Thus, in the "global" 
historical memory, Argentina was a proliferation country, an attribute which is likely to have an impact on the future of Argentine nuclear development. A 2010 report from the International Panel on Fissile Materials, based at Princeton University, succinctly explained: “Argentina's interest in enrichment goes back to the nuclear-weapon program that it abandoned in tandem with Brazil in 1990" [Hippel, 2010]. In the parallel world constructed by a group of nuclear "experts" there is no doubt that Argentina attempted to build a bomb.

Boyer, P. (1994). By the Bomb's Early Light. American Thought and Culture at the Dawn of the Atomic Age. Chapel Hill: The University of North Carolina Press, pp. 109-130.

Buch, T. (1998). ‘La proyección comercial internacional'. In: La cooperación internacional de la Argentina en el campo nuclear. Ed. by J. Carasales and R. Ornstein. Buenos Aires, Argentina: CARI, pp. 147-205.

Chase-Dunn, C. and Reifer, T. (2002). US Hegemony and Biotechnology: The Geopolitics of New Lead Technology. Working Paper 9. Riverside, U.S.A.: Institute for Research on World Systems, University of California, pp. 331-49, 1-12, 6. URL: https://escholarship.org/uc/item/3s38g8m5 (visited on 10th December 2014).

Etzkowitz, H. and Leydesdorff, L. (2000). 'The dynamics of innovation: from National Systems and 'Mode 2' to a Triple Helix of university-industry-government relations'. Policy Research 29 2, pp. 109-123, 109.

Evans, P. (1979). Dependent Development. The Alliance of Multinational, State, and Local Capital in Brazil. New Jersey, U.S.A.: Princeton University Press, p. 34.

Christian Science Monitor (1982). 'Falklands defeat could speed Argentine A-bomb'. Christian Science Monitor (16 June), p. 22.

Goldman, J. (1990). 'U.S. endorses Menem's nuclear plans'. Bulletin of the Atomic Scientists 466, pp. 9-10.

Hall, T. and Chase-Dunn, C. (2006). 'Global Social Change in the Long Run'. In: Global Social Change. Historical and Comparative Perspectives. Ed. by C. Chase-Dunn and S. Babones. Baltimore, U.S.A.: The Johns Hopkins University Press, pp. 33-58, 49.

Hippel, F. V., ed. (2010). The Uncertain Future of Nuclear Energy. International Panel on Fissile Materials, Research Report 9. Princeton, p. 68.

Hofmann, P. (1976). 'Atomic Agency Says It Is Bypassed'. New York Times (24 October), p. 20.

Hurtado, D. (2014). El sue no de la Argentina atómica. Tecnología, política nuclear y desarrollo nacional. Buenos Aires, Argentina: Edhasa.

Hurtado, D. and Feld, A. (2010). 'La revista Mundo Atómico y la 'Nueva Argentina' científica (1950-1955)'. In: Ideas y debates para la Nueva Argentina. Revistas culturales y políticas del peronismo (1946-1955). Ed. by C. Panella and G. Korn. La Plata, Argentina: Edulp, pp. 199-228.

Hymans, J. (2001). ‘Of Gauchos and Gringos: Why Argentina Never Wanted the Bomb, and Why America Thought It Did'. Security Studies 103, pp. 153-185.

International, U. P. (1982). 'Report Says Argentina Might Have Bomb Soon'. Washington Post (14 May), p. A8.

Katz, J. (2009). 'Innovación, tecnología y desarrollo en la economía argentina'. In: Del Ford Taunus a la soja transgénica. Reflexiones en torno a la transición argentina al siglo XXI. Ed. by J. Katz. Buenos Aires, Argentina: Edhasa, pp. $29-49,44$. 
Kessler, R. (1989). 'Peronists seek 'nuclear greatness'. Bulletin of the Atomic Scientists 454 , pp. 13-15.

Kondracke, M. (1982). 'The Falklands, the 'Latin Bomb' and Nuclear Proliferation'. Wall Street Journal (27 May), p. 29.

Leigh, C. (1984). 'Washington's Nuclear Policy Bombs Out in Argentina'. Wall Street Journal (28 September), p. 1.

Mallea, R. (2012). ‘La cuestión nuclear en la relación argentino-brasile na (1968-1984)'. Master thesis. Rio de Janeiro, Brazil.

Modelski, G. and Thompson, W. (1996). Leading Sectors and World Powers. Columbia, U.S.A.: University of South Carolina.

Nochteff, H. (1992). Evolución reciente del complejo electrónico en la Argentina y lineamientos para su reestructuración. Documento de Trabajo N. 42, LC/BUE/L.124. Buenos Aires, Argentina: CEPAL.

Novitski, J. (1974). 'Argentina: Nuclear Power'. Washington Post (26 December), p. 20.

Oster, P. (1985). 'Argentina nearing goal of nuclear bomb'. Houston Chronicle (23 April), p. 10.

Patterson, W. (1984). The Plutonium Business and the Spread of the Bomb. London, U.K.: Granada Publishing, p. 47.

Clarín (1992). ‘Por la suspensión del envío nuclear a Irán. Acusan al canciller de 'apartheid tecnológico". Clarín (11 March), p. 15.

La Prensa (1972). 'Posibilidades nucleares de la Argentina'. La Prensa (14 June), pp. 1-2, 1.

Pyenson, L. (1985). Cultural Imperialism and Exact Science. New York, U.S.A.: Peter Lang, pp. 139-246.

Ragin, C. and Chirot, D. (1995). 'The World System of Immanuel Wallerstein: Sociology and Politics as History'. In: Vision and Method in Historical Sociology. Ed. by T. Skocpol. $2^{\text {nd }}$ edition (1 ${ }^{\text {st }}$ edition, 1984). Cambridge, U.K.: Cambridge University Press, pp. 276-312, 298.

Redick, J. (1972). Military Potential of Latin American Nuclear Energy Programs. Beverly Hills / London: Sage Publications.

- (1975). 'Regional Nuclear Arms Control in Latin America'. International Organization 29 2, pp. 415-445, 419-420.

Reiss, M. (1995). Bridled Ambitions. Why Countries Constrain Their Nuclear Capabilities. Washington D.C., U.S.A.: The Woodrow Wilson Center Press, p. 45.

Rennstich, J. (2008). The Making of a Digital World: The Evolution of Technological Change and How It Shaped Our World (Evolutionary Processes in World Politics). New York, U.S.A.: Palgrave MacMillan.

Sabato, J. (1968). 'Energía Atómica en Argentina'. Estudios Internacionales 23, pp. 332-357, 333.

Sabato, J. and Botana, N. (2011). ‘La ciencia y la tecnología en el desarrollo futuro de América Latina'. In: El pensamiento latinoamericano en la problemática ciencia-tecnología-desarrollo-dependencia. Ed. by J. Sabato. $2^{\text {nd }}$ edition $\left(1^{\text {st }}\right.$ edition, 1968). Buenos Aires, Argentina: Ediciones Biblioteca Nacional, pp. 215-231.

Sabato, J. and Frydman, R. (1976). 'La energía nuclear en América Latina'. Estrategia 42 , pp. 54-62, 61.

SIPRI (1972). World Armaments and Disarmament. SIPRI Yearbook. Stockholm, Sweden: Almqvist \& Wiksell.

- (1986). World Armaments and Disarmament. SIPRI Yearbook. Oxford, U.K.: Oxford University Press, p. 477. 
Solingen, E. (1996). Industrial Policy, Technology, and International Bargaining: Designing Nuclear Industries in Argentina and Brazil. Stanford, CA, U.S.A.: Stanford University Press.

Sullivan, W. (1969). 'Pugwash Parley in Sochi told of Argentina's Nuclear Plans'. New York Times (27 October), p. A19.

Wallerstein, I. (1974). 'The Rise and Future Demise of the World Capitalist System: Concepts for Comparative Analysis'. Comparative Studies in Society and History 164, pp. 387-415, 404-405.

Watson, C. (1987). 'Will Civilians Control the Nuclear Tiger in Argentina?' In: On the Brink. Nuclear Proliferation and the Third World. Ed. by P. Worsley and K. B. Hadjor. London, U.K.: Third World Communications, pp. 209-214, 209.

Author

Diego Hurtado is professor of history of science and technology at National University of San Martín and member of the board of directors of the Argentine Nuclear Regulatory Authority. His research interests include the analysis of ideologies, representations and discourses in the processes of elaboration of technological policies in semi-peripheral countries. E-mail: dhurtado@arn.gob.ar.

\section{How to cite}

Hurtado, D. (2015). 'Semi-periphery and capital-intensive advanced technologies: the construction of Argentina as a nuclear proliferation country'. JCOM 14 (02), A05. 